Marquette University

e-Publications@Marquette

College of Education Faculty Research and

Publications

Education, College of

$11-1-2007$

\title{
Reclaiming the Moral in the Dispositions Debate
}

TerryJ. Burant

Marquette University, terry.burant@marquette.edu

Sharon Chubbuck

Marquette University, sharon.chubbuck@marquette.edu

Joan Whipp

Marquette University, joan.whipp@marquette.edu

Accepted version. Journal of Teacher Education, Vol. 58, No. 5 (December 2007): 397-411. DOI. (C)

2007 SAGE Publications. Used with permission. 


\title{
Reclaiming the Moral in the Dispositions Debate
}

\author{
Terry J. Burant \\ Educational Policy and Leadership, Marquette University \\ Milwaukee, WI \\ Sharon M. Chubbuck \\ Educational Policy and Leadership, Marquette University \\ Milwaukee, WI \\ Joan L. Whipp \\ Educational Policy and Leadership, Marquette University \\ Milwaukee, WI
}

This article addresses the current debates about the definition and assessment of dispositions in teacher education. Competing perspectives on the definitions and assessment of dispositions in teacher education are examined and critiqued, and a renewed commitment to foregrounding the moral nature of teaching is suggested. Recommendations for understanding and assessing the moral in teacher education, including the development of a code of ethics for the profession, are provided.

Since the advent of the standards movement in teacher education, the National Council for Accreditation of Teacher Education (NCATE), the Interstate New Teacher Assessment and Support Consortium (INTASC), and many state accreditation agencies use the term disposition in their standards for the preparation, assessment, and professional development of teachers. Combined with increased 
pressure from federal legislation like No Child Left Behind (NCLB) as well as accreditation requirements to systematically collect and aggregate data that demonstrate the assessment of dispositions, there is, of late, escalating interest in the definition and measurement of teacher candidate dispositions. Paralleling this credentialing activity, the American Association of Colleges for Teacher Education's (AACTE) Task Force on Teacher Education as a Moral Community reenergized conversations on the moral and ethical dimensions of teacher education; more recently, this group published a monograph (Sockett, 2006) to assist teacher educators grappling with both understanding and addressing standards for dispositions.

This attention to dispositions and their assessment in the profession has been accompanied by several incidences (e.g., at Brooklyn College, LeMoyne College, and Washington State University) when pre-service teachers challenged their teacher education programs' efforts to evaluate their dispositional development (Gershman, 2005). These events sparked polarized and politically charged editorials in the popular press claiming that teacher education programs are using dispositions as a device to keep good teachers out of the classroom on ideological grounds (see Gershman, 2005; Leo, 2005; Will, 2006). For example, in Newsweek, George Will (2006) argued that all schools of education should be shut down because of the way that they "discourage, even disqualify, prospective teachers who lack the correct 'disposition,'" which he defined as an "embrace [of] today's 'progressive' political catechism" (p. 98).

Many of the criticisms raised in the popular press are not surprising. Although the emphasis on dispositions in the teacher education community is clear, our definitions and measures are not. For example, NCATE initially defined dispositions as follows:

The values, commitments, and professional ethics that influence behaviors towards students, families, colleagues, and communities, and affect student learning, motivation, and development as well as the educator's own professional development. Dispositions are guided by beliefs and attitudes related to values such as caring, fairness, honesty, responsibility and social justice. For example, they might include a belief that all students can learn, a vision of high and challenging standards, or a commitment to a safe and supportive learning environment. (NCATE, 2006a)

Dispositions emerge in this description as a confusing muddle of 
"values" that are "guided by beliefs and attitudes that are related to values" and "might include a belief" that ultimately influences behaviors.

NCATE has recently attempted to address the confusion and accompanying criticism. In response to John Leo's (2005) editorial accusing schools of education of using "disposition theory" to impose a "group think" of "culturally left agenda" associated with social justice, Arthur Wise (2005), president of NCATE, disavowed any ideological tendencies in NCATE, including any official NCATE disposition toward social justice, although he cleverly questioned whether anyone would propose adopting a goal of social injustice. According to Wise, the professional dispositions needed to help all children learn-"honesty, responsibility, fairness" (Wise, 2005)-derive from the creation of model core state-licensing standards created in 1992 under the aegis of the Council of Chief State School Officers and embraced by INTASC, which form the basis for most state licensing standards. A closer look at these core licensing standards revealed 36 dispositions that extend far beyond such core constructs as "honesty, responsibility, and fairness" (INTASC, 1992).

Later, Wise (2006) pointed out factual flaws in the criticisms leveled against both institutions of teacher education and NCATE as the widely employed accrediting body. More significant, Wise defended NCATE's inclusion of dispositions as a standard to be evaluated, specifically naming two professional dispositions-fairness and belief that all students can learn-that are expected in candidates graduating from teacher education programs meeting accreditation standards. He also defended the legitimacy of each institution of teacher education selecting its own set of desired dispositions. Wise identified possible program-selected dispositions that range from the controversial to those more commonly accepted. On the more controversial end is the University of Alabama's commitment to "promote social justice . . . and to recognize individual and institutionalized racism." This commitment was an effort to learn from the state of Alabama's past mistakes of supporting racial discrimination and segregation, according to an unpublished letter written by the dean of the University of Alabama's College of Education (Wise, 2006). The more generally accepted dispositions that Wise named include those found in teachers who are caring, collaborative, and reflective. According to Wise, these 
and any other dispositions are not to be measured in isolation; they are to be measured only as translated into observable behaviors.

In several iterations, NCATE has continued to address the confusion surrounding dispositions. For example, one revised definition that appeared in a list of "Glossary Additions and Edits" dated March 2006 reads:

Professional dispositions: The behaviors demonstrated as educators interact with students, families, colleagues, and communities, which are expected of professionals and support student learning and development. NCATE expects candidates to demonstrate classroom behaviors that are consistent with the ideas of fairness and the belief that all students can learn. Based on their mission, professional education units may determine additional professional dispositions they want candidates to develop. NCATE expects institutions to assess professional dispositions based on observable behavior in educational settings. (NCATE, 2006b)

More recently, the glossary of the NCATE standards that were adopted in spring of 2007 that will go into effect in fall 2008 reads, "The definition of professional dispositions: To be determined," indicating that more work will be done in this critical area in the near future.

Although the responses offered by Wise and NCATE begin to provide much-needed clarity, especially in the naming of two primary dispositions-fairness and a belief that all children can learn-the position remains confusing. In the Board Action's revised definition (NCATE, 2006b), convoluted reasoning abounds as dispositions are defined as "behaviors," consistent with "ideas" and "belief," that are then assessed based on "observable behavior." The circular reasoning likely reveals more reaction to stinging criticism than logic in examining how the issue of dispositions may be flawed either in the policies of NCATE or in the field of teacher education. The "to be determined" nature of professional dispositions in the more recently adopted standards that will go into effect in fall 2008 suggest that NCATE is cognizant of the need for continued study and discussion.

In 2005, Schussler, Stooksberry, and Bercaw observed that there is a "paucity of literature directly addressing the dispositions of teacher candidates, particularly in clearly defining dispositions and offering means by which to authentically engage teacher candidates 
and teacher educators in their identification, analysis and development" (p. 2). The continuing lack of clarity around dispositions requires internal examination and clarification of what we mean by dispositions, the role that they play in the preparation of candidates fit for teaching, whether they can and should be assessed, and if so, in which ways and with which tools. Indeed, the task of engaging in serious study, reflection, and dialogue around the issue of dispositions is far from complete and seriously overdue. Although the most salient reason for reexamination is improvement of our work, at this point, as a profession, we must also proactively critique our own thinking and policies about dispositions lest we become victims of critical reaction, some misplaced and some warranted by our own lack of clarity.

In this article, we offer a conceptual analysis of various literatures surrounding the dispositions debate to clarify and critique how dispositions are currently framed and understood in teacher preparation. We summarize three common approaches to understanding and assessing dispositions and critique the limitations of each. We then present recommendations that can serve as a framework for continued discussion.

\section{Analysis of Literature Salient}

The current emphasis on dispositions, sparked by demands to hold teacher education programs accountable for outcomes, flows from a multifaceted history of research and discussions about requisite dispositions and qualities of effective teachers, described variously as personality variables (Gage, 1963a), temperament, attitudes (Getzels \& Jackson, 1963), beliefs (Richardson, 1996), manner (Fenstermacher, 1992), morals, and virtues (Sockett, 2006). Conceptualizing and identifying dispositions currently fall into three general categories in the literature: belief statements, personality traits, and inference from behaviors. Accompanying these various approaches are suggested avenues for measuring them. Although each approach offers perspective on the question of dispositions, each is significantly flawed.

\section{Dispositions as Beliefs and Attitudes}

Connecting dispositions to beliefs reflects the considerable emphasis on teacher beliefs research in recent years (Kagan, 1992; Nespor, 1987; Pajares, 1992; Richardson, 1990, 1996). There is some 
agreement about the relationship of knowledge to beliefs; the connections between emotion, affect, and beliefs; the role of prior experience in developing and sustaining beliefs; the episodic nature of beliefs; and their resiliency even in light of conflicting information or experience (Richardson, 1996). Most of this research suggests the need for greater emphasis in teacher education on interrogating and surfacing beliefs, analyzing beliefs in action, and reflecting on practice, often with the assistance of a critical partner(s) or using practical arguments (Fenstermacher, 1994).

In this framework, dispositions are linked to humanistic, existential belief statements (Mullin, 2003) often closely aligned with content-filled propositional statements. They follow a consistent model, beginning with an affective focus (Wilkerson, 2006) stated as, "The candidate believes/values/appreciates/recognizes . . . " followed by a statement of content. In recent years, much of this "belief and attitude" linked to content approach reflects the grave concern among educators about the differential academic achievement among culturally diverse students as well as the striking disconnect between the cultures of the increasing number of diverse students and their teachers (Garmon, 2004; Haberman, 1996; Hollins \& Guzman, 2005; Peterson, Cross, Johnson, \& Howell, 2000; Sleeter, 2001). Attempts to measure beliefs typically use Likert-type scale surveys or questionnaires (Dee \& Henkin, 2002; Pettus \& Allain, 1999; Pohan \& Aguilar, 2001; Sachs, 2004) or written reflections (Abernathy, 2002; Strickland, Weinstein, Thomas, Pierce, \& Stuckey, 2005). Although attention has been directed toward evaluating the efficacy of various dispositional measures using belief statements (Brown, 2004), little research explores the link between these beliefs and actual teacher efficacy, with some results actually showing little correlation (Sachs, 2004).

Equating dispositions with content-laden belief statements is problematic, however, in at least two ways. At the simplest level, students' responses to belief statement measures may reflect their ability to read their professors' expectations and supply the answer most likely desired by faculty, revealing little about the dispositions of the candidates. Wilkerson (2006) has argued that candidates' affective attitudes toward specific content and behavior need to be assessed lest they abandon those behaviors when their professors are no longer looking. Candidates who are that disingenuous, however, will have 
little problem being as deceptive about their affect and belief as they are about their behaviors.

Still, even if students provide sincere answers, this approach is conceptually flawed. Although teacher candidates may at times indicate the nature of their dispositions by the responses they give to Likert-type scale test items or in written reflections, that indication is certainly not a given. For example, one disposition included in the INTASC (1992) document "Model Standards for Beginning Teachers' Licensing, Assessment, and Development: A Resource for State Dialogue" states, "The teacher appreciates the cultural dimensions of communication. He/She responds appropriately, and seeks to foster culturally sensitive communication by and among all students in the class" (p. 25). Another disposition is stated as follows: "The teacher realizes that subject matter knowledge is not a fixed body of facts but is complex and ever-evolving" (INTASC, 1992, p. 14). Although dispositions may be inherent in these statements from INTASC, the greater emphasis in the statements is on an exposure to knowledgesuch as a rudimentary introduction to sociolinguistics or the historical development of a content area discipline-that would inform such recognition. This flaw may be even more pronounced in attempts to assess the meaning of pre-service candidates' level of agreement with specific test items related to racial, class, or gender diversity-for instance, "Students from lower socioeconomic backgrounds typically have fewer educational opportunities than their middle-class peers" or "Teachers often expect less from students from the lower socioeconomic class" (Pohan \& Aguilar, 2001). Pre-service teachers' responses may be the result of limited cultural experience or lack of exposure to specific information, revealing more about their knowledge acquisition than their potential dispositional orientation toward the content. When students are presented with theoretical and empirical information on the topics being assessed, when they have more extensive field exposure, or when they experience greater maturation, perhaps even occurring after program completion, their responses to the belief statements may very well change.

Simply put, equating dispositions with agreement with contentladen belief statements reduces dispositions to acquisition of an identified knowledge base, in effect erasing the distinction between knowledge and dispositions. A more accurate understanding is to break the supposed connection between belief statements and 
dispositions and instead call belief statements what they arestatements of knowledge-because they so frequently reflect what a pre-service teacher has had opportunity to learn. Pre-service teachers' willingness to accept the knowledge or to imbue it with personal interpretation or commitment may very well rest on the dispositions that they possess; the belief statements themselves, however, are better understood as knowledge.

\section{Dispositions as Personality Traits}

A second approach, one that has been labeled a psychodynamic approach (Mullin, 2003), defines dispositions as personality traits that produce consistent patterns of behavior in individuals. This understanding of dispositions surfaced in the field of education several decades ago. In the preface to the first Handbook of Research on Teaching, Gage (1963b) argued that the "personality and characteristics" of the teacher is one of the three "central variables" important in teaching and in research on teaching (p. vi). Gage distinguished characteristics like "the teacher's age, sex, social class, and years of experience" (p. vii), from personality traits or "individual differences among teachers in ability, knowledge, attitude, temperament, and the like" ( $p$. vii). In the scientific language of the time, Getzels and Jackson (1963) suggested that "the personality of the teacher is a significant variable in the classroom. Indeed, some would argue, it is the most significant variable" (p. 506). During this era, educational researchers sought to determine and measure the particular "human characteristics on which teachers differ and which can be hypothesized to account, in part, for differences in teacher effectiveness" (Gage, 1963a, p. 119) using instruments like the Minnesota Teacher Attitude Inventory (MTAI), the Minnesota Multiphasic Personality Inventory (MMPI), Guilford Personality Inventories, the Authoritarianism F-Scale, and a host of other measures of temperament, along with behavior observation and rating scales, to suggest relationships between personality variables and student performance. Ryans' (1960) extensive Teacher Characteristic Study, for example, was designed to assist administrators and teacher educators in selection of teachers and teacher candidates based on their characteristics.

These major studies of personality variables and their connections to teaching effectiveness revealed varied findings, even 
"pedestrian results" (Getzels \& Jackson, 1963, p. 579), in part because of the wide variety of theories of personality in use, the complexity of the construct, and the atheoretical nature of much of the research. As a result, until recently, little research in this area continued. In fact, Munby, Russell, and Martin (2001) considered Getzels and Jackson's chapter in Gage's 1963 Handbook of Research on Teaching as "mark[ing] the close of work on teacher personality" (p. 891). Current interest in teacher dispositions, however, has generated renewed efforts to develop teacher disposition assessment instruments based on personality traits. The Educational Testing Service (ETS), for example, is currently developing such a tool based on the Big Five personality traits (Roberts, 2006), including such continua as introversion/extroversion and agreeableness/criticality. This emerging work appears to focus on the development of a formative, rather than summative, tool to support development of dispositions deemed appropriate rather than to serve as a screen for candidates with inappropriate dispositions.

This psychological approach is also problematic for several reasons. Knowledge and skills can be learned and chosen; Wise's (2005) examples of ethical dispositions-honesty, responsibility, and fairness-can be learned and chosen. The long-held definition of dispositions held in the community of behavioral scientists, on the other hand, is distinctly different in that it lacks that element of choice. According to Damon (2005), dispositions as used in the field of psychology refers to those characteristics of personality that develop early in life and significantly influence the development of one's life course. In Damon's words, "A disposition is a 'trait' or 'characteristic' that is embedded in temperament and 'disposes' a person towards certain choices and experiences that can shape the person's future" in a manner relatively constant over time and individual development. For the field of teacher education to adopt the term without adhering to its accepted meaning in the field in which it is most frequently employed (a field, for better or worse, that has a strong historical connection to teacher preparation) reveals, at best, naïve thinking associated with the academic silo effect and, at worst, short-sighted arrogance. To adopt the term while supplying our own definition leaves the field of teacher educators vulnerable to looking foolish and uninformed. 
If we were to adopt the more widely accepted understanding of the term, however, problems still remain. Personality traits, such as "extroversion" or "agreeableness" (Pervin \& John, 1999), may support teacher quality in some cases. However, conflating dispositions with relatively immutable personality traits is based on troublesome assumptions that good teachers, whatever their context or discipline, should all possess an identifiable set of specific personality traits, and that all students, themselves aggregately representing the entire spectrum of known personality traits, will learn from teachers who homogenously possess that one limited set. As earlier researchers (Washburne \& Heil, 1960) noted, the personality of the student interacts with the personality of the teacher, making it implausible and futile to search for the personality qualities of the ideal teacher. In addition, a focus on personality traits could reduce the job of teacher educators to gatekeepers who administer psychological tests at the point of program entry, based on an assumption that screening out candidates who lack the "good teacher" personality traits is necessary. These assumptions are neither empirically verifiable nor logically reasonable. Furthermore, if the dispositions listed under the INTASC (1992) core standards (e.g., honesty, fairness, responsibility) are the goals that we aspire to reach, the notion of personality traits is misplaced and the term disposition is inaccurate and problematic.

\section{Dispositions Inferred From Observable Behaviors}

A final approach to understanding dispositions identifies them as meaningfully understandable and measurable primarily when directly linked to behaviors (Diez, 2006; Mullin, 2003; NCATE, 2006b; also, G. Ladson-Billings, personal communication, February 1, 2005). This approach matches the somewhat ambiguous directions of NCATE for teacher education units to measure dispositions initially in terms of students' "familiarity" with dispositions and then indirectly as implied in observable behaviors (NCATE, 2006a). Wise (2006) clarified that ambiguity by stating unequivocally that dispositions are measured "by translating them into observable behaviors in school settings." A later version, albeit still confusing, attempt to clarify the definition of dispositions (NCATE, 2006b) places an even greater emphasis on this approach by explicitly equating dispositions with behaviors and linking their assessment exclusively to observable behaviors. This approach is particularly complex because of the muddy linkage that exists between

Journal of Teacher Education, Vol. 58, No. 5 (November/December 2007): pg. 397-411. DOI. This article is C SAGE Publications and permission has been granted for this version to appear in e-Publications@Marquette. SAGE Publications does not grant permission for this article to be further copied/distributed or hosted elsewhere without the express permission from SAGE Publications. 
a person's interior values and his or her behavior. The interiority of an individual is inherently and ultimately inaccessible to the observer and attempts to externally identify and measure an individual's interior reality are the grist of courtroom debate and the fodder of potential lawsuits. Yet common sense and experience tell us that behavior can accurately be described as frequently, if not always, flowing congruently from interior values, dispositions, and moral convictions. This complexity, then, calls for a more nuanced analysis.

Evaluating teacher behaviors has a considerable history in research on teaching (see Medley \& Mitzel, 1963). Earlier efforts often conflated behaviors with dispositions, with measurement frequently relegated to simple behavioral checklists that are ineffective in their reductionist nature. This approach is still in practice as institutions attempt to provide proof of their candidates' appropriate dispositions via observations of behavior, proof that is then distilled into reports of aggregated, numerical data for accreditation purposes. Although preservice teachers' behaviors may indeed indicate dispositions, this approach is problematic at several levels.

Using behaviors as a starting point for determining dispositions requires a clean chain of cause and effect; in reality, the inference is imprecise. Any given behavior, whether interactive or pedagogical, may or may not reflect a specific disposition. The behaviors of candidates may tell us more about their knowledge of appropriate skills, their conviction concerning the value of a given practice, or a reading of the classroom context via novices' eyes, leaving identification of the underlying dispositions open to considerable misinterpretation. Attempts to relate dispositions to specifically identified pedagogical behavior are also inherently risky given the consistent shifts in thought as to what constitutes best practice, for which students, and in what contexts. A spot check of the history of pedagogical theory during the past 50 years reveals widely varied recommendations, often based on such slippery elements as the topics chosen for study, the sample of participants studied, the research methodology used, and the ideological perspective of the researcher. Yet even if we were able to limit this process to current recommended practices, the approach is still suspect given the widely divergent thinking about what constitutes good practice at any grade level or in any content area. Controversies surrounding such issues as ability grouping or subject-level tracking, classroom management, or 
teaching reading demonstrate the potential minefield of linking dispositions too closely to specific pedagogical approaches.

In addition to this ambiguity, the problems associated with determining the dispositions that underlie behavior are amplified when the process rests on the perspectives of individual teacher educators alone. Accounting for the contextual and cultural differences in how teacher behaviors are understood and valued requires a broader base of stakeholders. For example, caring pedagogy often associated with White female teachers (Noddings, 1984) comprises a type of skills and knowledge manifested in a specific warm, nurturing style. Some educators of color, however, describe a pedagogy of caring displayed by effective African American teachers interacting with students of color that is marked by a much more demanding, strict style (Delpit, 1995; Foster, 1997; Thompson, 1998). Though distinctly different, both styles could spring from a similar disposition of care. Similarly, both styles of behavior could imply vastly different dispositions depending on the perspective of the evaluator. An accurate inference clearly requires perspective and insight drawn from cultural and contextual understanding. If dispositions are to be inferred from behaviors, teachers working in the local context, as well as parents of the children being served, must be included in the process.

If numerical checklists of behavior are abandoned and a broader base of stakeholders informs the assessment process, are there potentially successful ways to deduce dispositions from observed behaviors? Perhaps there are, through more qualitative, relationally based approaches, but even these must be approached cautiously because the level of inference remains significant lest behavior and disposition simply be equated. For example, to attribute dispositional motives to actions, the teacher educator must engage the pre-service teacher in conversation about belief statements connected to the behaviors exhibited and, from those belief statements, further infer the underlying dispositions. Although this method may be an admittedly legitimate attempt to safeguard against the vagaries of flawed inferences, the means of assessment can drive the definition of dispositions; the assessments could link observable actions to articulated belief statements without the underlying dispositions being clearly named. At worst, this approach either erases any meaningful distinction between dispositions and behaviors or simply returns to content-laden belief statements. The result is circular logic that can 
simply reinforce the initial inference. The danger of this circular reasoning is embedded in NCATE's (2006b) revised definition in which professional dispositions are conflated with behaviors.

At best, this more nuanced, qualitative approach can allow teacher educators to identify the dispositions that underlie and motivate a pre-service teacher's actions and, in fact, help the candidate understand dispositions and how they intersect and produce behaviors. In one program, qualitative interviews measured dispositions, understood behaviorally, in entry-level candidates. Before entering the teacher education program, students responded to openended questions about their activities; following were probes designed to elicit a sense of duration, intensity, frequency, and conditions of the behavior (Mullin, 2003). Diez (2006) described an intensive, thorough system for assessing dispositions based on observed behavior of candidates already involved in teacher education. This process involved collaborative dialogue between a teacher candidate and the teacher educator centered on the candidate's videotaped classroom performance. Through this discussion, teacher educators inferred the dispositions that motivated behavior, assessed the sufficiency of the behavior, and provided candidates with guidance, support, and, if warranted, encouragement to exit the program (Diez, 2006). This process holds considerable promise; however, the successful identification happens only when the observation is preceded by thorough and clear conversations on the nature of dispositions, the dispositions valued in a particular context, and the ways in which behaviors may or may not demonstrate the desired dispositions. Although this process may simply be good teacher education, when coupled with close observation and extensive follow-up interviews, the amount of faculty time required to do this well is considerable and, in some contexts, perhaps unrealistic.

Given the complications associated with inferring dispositions from observable behaviors, a better approach is to disentangle dispositions from observable behaviors. Let behaviors first stand as what they are: the skills that pre-service teachers demonstrate based on knowledge that they have acquired. This position aligns with the actual content of the INTASC list of dispositions (1992) where the affective belief statements are typically followed by statements implying observable actions, such as, "The teacher appreciates the cultural dimensions of communication. S/He responds appropriately, 
and seeks to foster culturally sensitive communication by and among all students in the class" (p. 25) and "The teacher realizes that subject matter knowledge is not a fixed body of facts but is complex and everevolving. S/He seeks to keep abreast of new ideas and understandings in the field" (p. 14). These behaviors may reflect dispositions; indeed, skills and dispositions are certainly not cleanly separate. Yet determining which specific behaviors accurately reflect the desired disposition will depend on several variables. Again, even when the behaviors are identified, they still must first be understood as skills framed by contextual and cultural nuance that may or may not have been learned by a pre-service teacher. The process of inferring a strong, clear connection to dispositions and using that inference as data to determine the dispositional suitability of teacher candidates for accreditation agencies is laden with potential pitfalls and abuses.

\section{Recommendations: A Moral Turn}

The preceding critique of literature surrounding the dispositions dilemma exposes flaws in how we currently think about and assess dispositions. Belief statements are best understood as acquired knowledge, not dispositions. Personality traits are too static, and teaching contexts are too fluid and complex to conceive of dispositions as a reduction of ideal personality traits for teachers. Observable behaviors, although they may reflect dispositions, often should be first understood as indicators of learned (or unlearned) skills and not as clear, uncomplicated indicators of dispositions. Yet critique without recommendation is disheartening and unproductive, and we are left with gaps waiting to be filled.

As an initial step, we suggest that the profession significantly dissociate itself from the term disposition and remove the word from the field's current trinity of knowledge, skills, and dispositions in its lexicon about professional standards for teachers. This move need not leave a moral vacuum in the profession; to the contrary, this extraction may provide several important opportunities. As currently employed in the accreditation process, the term dispositions is clumsily and inaccurately borrowed from the behavioral sciences, rendering it ineffectual; furthermore, given the amount of inflammatory baggage recently attached to it, the term's removal might circumvent continued controversy, even if only for a time. More important, removing the term can provide a greater space for revitalizing discussions for a 
richer understanding of the qualities that underlie knowledge and skills in those persons fit for teaching as well as some possible direction on how to form and to evaluate those qualities. To spark such discussion, we present the following recommendations.

\section{Reclaiming the Moral}

Our major recommendation, one that serves as an umbrella for those that follow, is to unabashedly resurrect and reclaim the moral in teaching. Teaching has long been understood as a moral activity with a rich history in philosophy (Beyer, 1997; Goodlad, Soder, \& Sirotnik, 1990; Hansen, 2001a, 2001b; Sockett, 2006: Strike, 1996). Across many generations, philosophers such as Confucius, Plato, Socrates, Aristotle, Kant, Herbart, and the like explicitly maintained that teaching, at heart, involves a moral relationship between a teacher and a student. Yet as the scientific curriculum-making forces of the early twentieth century gained a firm footing in teacher education (Kliebard, 1975), as foundations courses in philosophy of education dwindled in number, and as the mantra of accountability has been increasingly sounded in recent years, the field has nearly buried these fundamental and important ideas.

Sadly, the word moral often brings to mind images of a type of morality associated with strict prescriptions for individual thought and behavior, trepidation about wandering into religious territory, or fear of lawsuits. Yet the moral dimensions in teacher education-not to be conflated with this narrow notion of morality - involve viewing the moral in teaching as an "orientation towards practice, a way of perceiving the work and its significance" that manifests itself in "countless forms of human interaction" (Hansen, 2001b, p. 827) in the classroom and in schools. Dewey embraced a pragmatic understanding of the moral as a constant consciousness that knowledge and one's actions based on knowledge interact in the social world with significant consequences on others (Hansen, 2006). In that understanding, moral and ethical implications attend all our actions; acknowledging and examining these implications is our responsibility as members of society and especially as teachers and as teacher educators. Rather than abdicating the dialogue and allowing a default definition of the moral to prevail-one that is often ineffective in its rigidity-reclaiming this broader view of the moral ultimately may be liberating because it could provide the space for assisting future teachers in developing an 
expanded, clarified understanding of the importance of contextualizing knowledge and its effects in the social world. Conversations with preservice teachers about the moral aspects of teaching provide an opportunity to say, "No, this isn't what we mean by moral. Instead, this is what we mean and this is why."

So what do we mean? Given an embrace of the moral as the content that deserves our attention, we suggest that there are two distinctive ways in which a moral turn can be understood and employed in teacher education. The first relies on Hansen's (2001a) notion of "moral sensibility," and the second involves a code of ethics for the profession. This twofold distinction in understanding the moral, in turn, opens the door for greater clarity in assessment. Although this discussion, at first glance, may appear to be a semantic exercise of substituting terms, we believe that this analysis of the space formerly known as dispositions can serve the field well.

\section{Moral sensibility}

According to Hansen (2001a), a moral sensibility, reflected in both thought and emotion and apparent in the "way in which a teacher thinks and acts" (p. 33; emphasis in original), connects both who a teacher is as well as his or her conduct "under a unifying outlook or orientation" (p. 39). In other words, a moral sensibility is an orientation toward the student and the profession that serves as the foundation of teacher thought and action. Thus, a moral sensibility (or its lack) produces, underlies, shapes, and sustains what the teacher knows, how the teacher makes sense of that knowledge, and the ways in which the teacher chooses to act in response to knowledge and circumstances. This moral sensibility is more deep-seated than either measurable beliefs or observable behaviors and, though perhaps related to personality traits, it is less static and immutable and can be encouraged, learned, and chosen. Though a moral sensibility may be manifested and made visible in behaviors, such as making oneself available to students after hours or giving students multiple opportunities to succeed in a class, and may prompt belief statements, such as the conviction that all children can learn, it is deeper and more foundational than either knowledge or skills. As Hansen (2001a) explained, "A teacher's moral sensibility should be understood as an achievement in its own right . . . it is not like a tool that a teacher 
pulls out of a box and then replaces once he or she has done the sensible thing" (p. 38).

Examples of the qualities needed in teachers, identified by numerous educators over time, consistently reflect the ingredients of a moral sensibility. Dewey (1933/1964), for example, described important qualities needed for reflective thinking: open-mindedness, wholeheartedness, and intellectual responsibility; Freire (1998) described qualities of progressive teachers including humility, lovingness, courage, patient impatience, and a joy of living, among others. Haberman (1996) similarly identified a set of personal qualities found in the teachers whom he deemed "star teachers" for urban students, including persistence, caring, personal responsibility, love of learning, courage, confidence, reflectivity linked to action, and humble admission of fallibility. In various Catholic institutions of higher education, intellectual competence, openness to growth, reflectivity, lovingness expressed in deeds as well as words, cura personalis (care for the whole person), an action-oriented solidarity with the poor, and a commitment to doing justice (International Commission on the Apostolate of Jesuit Education, 1994; Kolvenbach, 1993, 2000) are cited as critical attributes of teachers. Many of the aforementioned values or qualities comprise a moral sensibility and demonstrate the possible breadth of the category, a breadth that may invite local, contextualized determination of which qualities warrant attention, as Wise (2006) similarly suggested for dispositions.

\section{A code of ethics}

In the context of reclaiming the broad moral nature of teaching, there is also value in identifying a specific subset of that broader category in the form of a basic code of ethics. For our second recommendation, then, we call for the various organizations representative of the profession (e.g. American Association for Colleges of Teacher Education and Association of Teacher Educators) to create a set of specific, foundational ethics inherently connected to teaching. Ideally, this code would explicitly name those ethical qualities most fundamental to the professional practice of teaching and give clear descriptions of the behaviors that would or would not exemplify those ethical positions. Equally important, the code would be applied uniformly to the profession. 
This is an area in which the teacher education profession could benefit from the examples of other professional groups with codes of ethics and professional conduct. Most of these codes establish a similar set of values, with many providing elaboration on what these values would produce in terms of beliefs and behaviors in practice. For example, the American Psychological Association (APA, 2002) has established general principles of ethics, not as enforceable rules but as considerations for determining one's course of action. These include beneficence and nonmaleficence, fidelity and responsibility, integrity, justice, and respect for people's rights and dignity. The National Association of Social Workers (1999) lists five values that their members are expected to embrace: service, social justice, dignity and worth of the person, importance of human relationships, integrity, and competence. Both associations, then, follow the statement of ethical values with rather lengthy lists delineating examples of how each of these general principles or values might be enacted in daily practice. Apparently, these explicit standards of behavior, although not exhaustive, are viewed as guidelines for enforceable rules for conduct; assessment and any accompanying discipline are applied to the conduct and not to the general principles identified as underlying that conduct.

In the teaching profession, some codes of ethics already exist but without uniform acceptance across the field. For example, the National Education Association (NEA, 1975) adopted a code of ethics for the profession with three parts: a statement of ethical stances important in the profession (including respect, responsibility, believing in the worth and dignity of each human being, and devotion to excellence); the two principles of commitment to the student and commitment to the profession; and following each principle, a list of behaviors that should not occur. The Association of American Educators (2003) focuses more immediately on conduct than on values, establishing four contexts of ethical conduct-toward students, toward practice and profession, toward professional colleagues, and toward parents and community-with each followed by a description of primarily observable behaviors.

An examination of the various ways in which ethical codes are formulated, a consideration of what core ethical values may be requisite to the teaching profession, and significant elaboration on ways those ethical values may be expressed in behaviors would be an 
important step toward greater clarity of understanding, unity of practice, and professionalization of the field. AACTE's Task Force on Teacher Education as a Moral Community (Socket, 2006) already has begun discussions of this sort; the effort is commendable and could be expanded.

\section{Assessing the Moral}

If we believe that the moral is an essential piece of the teaching profession, then clearly, assessment of the moral is also necessary. This assessment, however, must be carefully considered; unfortunately, this point in time does not encourage nuanced thinking regarding assessment. As the language and methods of accountability have proliferated in teacher education, along with pressure to measure teacher dispositions, many programs have shifted emphasis away from the formation of qualities of moral sensibility toward the lesser end of measurement and summation, devolving into self-reports of belief statements and checklists of observable behaviors (see Diez, 2006). Not surprisingly, this emphasis on summative assessments has led to legal challenges from candidates whose moral sensibility does not "measure up." In addition, the pressure for measurement has too frequently driven the defining process, producing the aforementioned flawed understandings of dispositions and the language we use to talk about them, resulting in the ongoing confusion that plagues our field. For example, current interest in scientific measures of "teacher quality" has clouded or even discouraged other ways of framing discussions about the topic. We need to rescue moral sensibility from the current tendency to easily measure dispositions and aggregate numbers for accreditation purposes. Indeed, attempting to measure and quantify what may not be measurable or even knowable, given the ultimate inaccessibility of each person's interiority, may itself be an immoral, unethical action.

These two recommendations - an embrace of a far-reaching view of the moral sensibility that underlies all teaching and adoption of a focused, specific ethical code linked to conduct-allow us to view and evaluate the limits and the potential of assessment more carefully. Recognizing the difference between summative assessment or measurement and formative assessment and seeing how they apply respectively to specific ethical codes and to a broader moral sensibility can provide an element of the nuance that has been missing. 
First, we attend to the link between a proposed code of ethics and summative assessment. A code of ethics should be a more specific, focused subset of the larger category of moral sensibility; and, when accompanied by a clear description of the behavioral exemplars that would or would not indicate such ethics, such a code more readily lends itself to the sorts of codification required by summative assessment. For example, an unethical stance such as irresponsibility or disrespect for human dignity can be linked to observed behaviors and assessed through something close to measurement with fewer of the problems currently associated with summatively assessing dispositions. Though still not a clean, easily applied process, this narrower ethical category, with expanded description of possible scenarios, offers a much less problematic venue to summatively assess candidates' ethical readiness to teach. Identifiable, egregious breaches of ethical standards of behavior might warrant remediation or dismissal from a teacher education program. Establishing such a code and a corresponding uniform protocol of response to those breaches, therefore, is of great importance to the field in both increasing the professionalism of the teaching field as well as diminishing the possibility of distasteful and damaging lawsuits. Other professions can offer wisdom for these processes.

The more complicated question centers on the assessment of the larger realm of moral sensibility. To untangle this, we need to return to the etymological definition of assess, which comes from the Latin verb "assidere," meaning to "sit by." The implication is that we sit with and accompany learners while they are learning rather than simply apply some form of measurement at an end point to determine whether they have indeed learned. Such a view suggests that assessment be part of a developmental process, that it be largely formative in nature. For this reason, we need to pay attention to ways by which teacher candidates can be guided not only in their development of knowledge and skills but also in the deeper moral sensibility that serves as the foundation for their use of that knowledge and those skills in teaching. (See Diez, 2006, for helpful examples of formative assessment practices in this area). The teacher educators' interaction with pre-service teachers around moral sensibility, then, is less about measurement and more about teaching and learning. This is an area for which renewed research on the nature 
of the moral in pre-service teachers is necessary (See Chubbuck, Burant, \& Whipp, in press).

Allowing accountability to outside accrediting agencies to become the overarching motivation for assessment of the moral in teacher education clearly is fraught with potential problems. In the process, we may produce a flawed, inaccurate product. Even more, we may lose sight of our responsibility as educators to actually engage pre-service teachers in the sorts of experiences and conversations that could illuminate these qualities of moral sensibility and encourage their growth. If attempting to measure and quantify the interiority of another's moral sensibility may itself be an immoral action, then failing to attend to the formation of that same moral interiority is equally if not more suspect. As Diez (2006) has argued, "Assessing dispositions should first provide information to help candidates into an understanding and practice of the moral expectations of teachers" ( $p$. $52)$.

\section{Future Dialogue}

We have offered analysis of the current confusion and inaccuracies surrounding the notion of dispositions as well as recommendations that could lead the profession out of confusion and into greater clarity. In sum, we believe that the field is better served by entirely removing the term dispositions from our conversation and by returning to a deeper and unapologetic understanding of teaching as a moral activity. We are eager to see our profession adopt a code of ethics to serve as a foundational moral grounding for the field, to offer guidelines for ethical behavior, and to provide relatively uniform responses to breaches of ethics.

At the same time, we are convinced that our attention in teacher education must shift considerably to the formation not only of knowledge and skills but also of the moral sensibility that underlies them. The moral nature of teaching cannot be conflated with the knowledge and skills important for teaching; neither can it be neatly separated from them (Ball \& Wilson, 1996; Bercaw, Schussler, \& Stooksberry, 2005; Oser, 1994; Sockett, 2006). As we have known throughout the ages yet also frequently ignore, the moral is always in play in classrooms in teachers' actions, whether intentionally or not, and the complexity of the classroom environment-its immediacy and ever-changing activities-makes demands on teachers that reveal their 
orientation to their work in a myriad of daily acts (Jackson, Boostrom, \& Hansen, 1993). Because of that seamless connection, explicit attention to the moral formation of pre-service teachers is crucial (Ball \& Wilson, 1996; Hansen, 2000; Joseph, 2000). Therefore, assessment of the qualities of moral sensibility must be primarily formative, as teacher educators "sit beside" teacher candidates in the collection of evidence and reflection on moral development as it relates to the teaching profession.

We call on ourselves, our colleagues, and the bodies that represent the field of teacher education to reclaim the moral: to continue this discussion, to embrace the questions that will surely emerge, and to reach a place of clarity from which we can move forward with a unified voice.

\section{Biography}

Terry J. Burant is an assistant professor in educational policy and leadership studies at Marquette University. Her research interests include teaching as a moral practice, early field experiences in teacher education, and teacher knowledge and fashion. Recent publications have appeared in Multicultural Perspectives, Ethics and Education, and Rethinking Schools.

Sharon M. Chubbuck is an assistant professor in educational policy and leadership studies at Marquette University. Her research interests include teacher dispositions, Whiteness, and social justice in education. Recent publications have appeared in American Educational Research Journal, Ethics and Education, and Christian Higher Education.

Joan L. Whipp is an associate professor and director of graduate studies in educational policy and leadership studies at Marquette University. Her research interests include disposition development in pre-service teachers, teacher learning and change, and technology use in teacher education. Recent publications have appeared in Journal of Teacher Education, Ethics and Education, and Educational Technology Research and Development.

\section{References}

Abernathy, T. V. (2002). Using a storybook prompt to uncover in-service and pre-service dispositions toward struggling students. Teacher Educator, $38(2), 78-98$.

American Psychological Association (APA). (2002). Ethical principles of psychologists and code of conduct. Retrieved May 23, 2006, from www2.apa.org/ethics/code2002.doc

Association of American Educators. (2003). Code of ethics. Retrieved June 28, 2007, from www.aaeteachers.org/ code-ethics.shtml 
NOT THE PUBLISHED VERSION; this is the author's final, peer-reviewed manuscript. The published version may be

accessed by following the link in the citation at the bottom of the page.

Ball, D. L., \& Wilson, S. M. (1996). Integrity in teaching: Recognizing the fusion of the moral and the intellectual. American Educational Research Journal, 33(1), 155-192.

Bercaw, L. A., Schussler, D. L., \& Stooksberry, I. M. (2005, April). The recursive nature of disposition domains of prospective teachers. Paper presented at the Annual Meeting of the American Educational Research Association, Montreal, Quebec, Canada.

Beyer, L. (1997). The moral contours of teacher education. Journal of Teacher Education, 48(4), 245-254.

Brown, K. M. (2004). Assessing preservice leaders' beliefs, attitudes, and values regarding issues of diversity, social justice, and equity: A review of existing measures. Equity \& Excellence in Education, 37, 332-342.

Chubbuck, S. M., Burant, T. J., \& Whipp, J. L. (in press). The presence and possibility of moral sensibility in beginning pre-service teachers. Ethics and Education.

Damon, W. (2005). Personality test: The dispositional dispute in teacher preparation today, and what to do about it. Retrieved May 25, 2006, from www.edexcellence.net/foundation/publication/ publication.cfm?id=343

Dee, J. R., \& Henkin, A. B. (2002). Assessing dispositions towards cultural diversity among pre-service teachers. Urban Education, 37(1), 22-41.

Delpit, L. (1995). Other people's children: Cultural conflict in the classroom. New York: New York Press.

Dewey, J. (1964). Why reflective teaching must be an educational aim. In R. D. Archambault (Ed.), John Dewey on education (pp. 313-338). Chicago: University of Chicago Press. (Original work published 1933)

Diez, M. (2006). Assessing dispositions: Five principles to guide practice. In H. Sockett (Ed.), Teacher dispositions: Building a teacher education framework of moral standard (pp. 49-60). Washington, DC: AACTE Publications.

Fenstermacher, J. D. (1992). The concepts of method and manner in teaching. In J. K. Oser, J. Dick, \& J. Patry (Eds.), Effective and responsible teaching (pp. 95-108). San Francisco: Jossey-Bass.

Fenstermacher, G. D. (1994). The place of practical argument in the education of teachers. In V. Richardson (Ed.), Teacher change and the staff development process: A case in reading instruction (pp. 23-42). New York: Teachers College Press.

Foster, M. (1997). Black teachers on teaching. New York: The New Press. Freire, P. (1998). Teachers as cultural workers: Letters to those who dare teach. Boulder, CO: Westview.

Journal of Teacher Education, Vol. 58, No. 5 (November/December 2007): pg. 397-411. DOI. This article is (C SAGE Publications and permission has been granted for this version to appear in e-Publications@Marquette. SAGE Publications does not grant permission for this article to be further copied/distributed or hosted elsewhere without the express permission from SAGE Publications. 
NOT THE PUBLISHED VERSION; this is the author's final, peer-reviewed manuscript. The published version may be accessed by following the link in the citation at the bottom of the page.

Gage, N. L. (1963a). Paradigms for research on teaching. In N. L. Gage (Ed.), Handbook of research on teaching (pp. 94-141). Chicago: American Educational Research Association.

Gage, N. L. (1963b). Preface. In N. L. Gage (Ed.), Handbook of research on teaching (pp. v-ix). Chicago: American Educational Research Association.

Garmon, M. A. (2004). Changing preservice teachers' attitudes/beliefs about diversity: What are the critical factors? Journal of Teacher Education, 55(3), 201-213.

Gershman, J. (2005). "Disposition" emerges as issue at Brooklyn College. Retrieved May 31, 2005, from www.nysun.com/article/14604

Getzels, J. W., \& Jackson, P. W. (1963). The teachers' personality and characteristics. In N. L. Gage (Ed.), Handbook of research on teaching (pp. 506-582). Chicago: American Educational Research Association.

Goodlad, J. I., Soder, R., \&. Sirotnik, K. (Eds.). (1990). The moral dimensions of teaching. San Francisco: Jossey-Bass.

Haberman, M. (1996). Selecting and preparing culturally competent teachers for urban schools. In J. Sikula (Ed.), Handbook of research on teacher education (2nd ed., pp. 747-760). New York: Macmillan.

Hansen, D. T. (2000, April). Cultivating an intellectual and moral sensibility as teachers. Paper presented at the Annual Meeting of the American Educational Research Association, New Orleans, LA.

Hansen, D. T. (2001a). Exploring the moral heart of teaching: Toward a teacher's creed. New York: Teachers College Press.

Hansen, D. T. (2001b). Teaching as a moral activity. In V. Richardson (Ed.), Handbook of research on teaching (4th ed., pp. 826-857). Washington, DC: American Educational Research Association.

Hansen, D. T. (2006, April). Moral knowledge as an aim of education: John Dewey. Paper presented at the Annual Meeting of the American Educational Research Association, San Francisco.

Hollins, E. R., \& Guzman, M. T. (2005), Research on preparing teachers for diverse populations. In M. Cochran-Smith \& K. M. Zeichner (Eds.), Studying teacher education: The Report of the AERA Panel on Research and Teacher Education (pp. 477-578). Mahwah, NJ: Lawrence Erlbaum.

Interstate New Teacher Assessment and Support Consortium (INTASC). (1992). Model standards for beginning teachers' licensing, assessment, and development: A resource for state dialogue. Retrieved May 25, 2006, at www.ccsso.org/content/pdfs/corestrd.pdf

International Commission on the Apostolate of Jesuit Education. (1994). Ignatian pedagogy: A practical approach, Section 14. In C. E. Meirose (Ed.), Foundations (pp. 237-269). Washington, DC: Jesuit Secondary Education Association.

Journal of Teacher Education, Vol. 58, No. 5 (November/December 2007): pg. 397-411. DOI. This article is C SAGE Publications and permission has been granted for this version to appear in e-Publications@Marquette. SAGE Publications does not grant permission for this article to be further copied/distributed or hosted elsewhere without the express permission from SAGE Publications. 
NOT THE PUBLISHED VERSION; this is the author's final, peer-reviewed manuscript. The published version may be accessed by following the link in the citation at the bottom of the page.

Jackson, P. W., Boostrom, R. E., \& Hansen, D. T. (1993). The moral life of schools. San Francisco: Jossey-Bass.

Joseph, P. B. (2000). Teaching about "the moral classroom": A moral lens for reflecting on practice. Paper presented at the Annual Meeting of the American Educational Research Association, New Orleans, LA.

Kagan, D. M. (1992). Implications of research on teacher belief. Educational Psychologist, 27(1), 65-90.

Kliebard, H. M. (1975). The rise of scientific curriculum-making and its aftermath. In D. J. Flinders \& S. J. Thornton (Eds.), The curriculum studies reader (2nd ed., pp. 37-46). New York: RoutledgeFalmer.

Kolvenbach, P. (1993, July 31). Ignatian pedagogy: A practical approach. Paper presented to the International Commission on the Apostolate of Jesuit Education. Washington, DC: Jesuit Secondary Education Association. Retrieved on August 25, 2007, from http://www.sjweb.info/education/doclist.cfm

Kolvenbach, P. (2000, October 6). The service of faith and the promotion of justice in American Jesuit higher education. Paper presented at the Commitment to Justice in Jesuit Higher Education Conference, Santa Clara University, Santa Clara, CA. Retrieved August 25, 2007, from http:// www.scu.edu/ignatiancenter/bannan/eventsandconferences/ justiceconference/nationalconference/ kolvenbach.cfm

Leo, J. (2005, October 24). Class(room) warriors. U.S. News and World Report. Retrieved August 24, 2007, from http://www.usnews.com/usnews/opinion/articles/ 051024/24john.htm

Medley, D. M., \& Mitzel, H. E. (1963). Measuring classroom behavior by systematic observation. In N. L. Gage (Ed.), Handbook of research on teaching (pp. 247-328). Chicago: Rand McNally.

Mullin, D. (2003, January 25). Developing a framework for assessing teacher candidate dispositions. Presentation at AACTE National Conference, New Orleans, LA.

Munby, H., Russell, T., \& Martin, A. (2001). Teachers' knowledge and how it develops. In V. Richardson (Ed.), Handbook of research on teaching (4th ed., pp. 877904). Washington, DC: American Educational Research Association.

National Association of Social Workers. (1999). Code of ethics for the National Association of Social Workers. Retrieved June 28, 2007, from http://socialworkers.org/pubs/code/code.asp

National Council for Accreditation of Teacher Education (NCATE). (2006a). Professional standards for the accreditation of schools, colleges, and departments of education, 2006 edition. Retrieved July 11, 2007, from http://www.ncate .org/institutions/standards.asp?ch $=4$

Journal of Teacher Education, Vol. 58, No. 5 (November/December 2007): pg. 397-411. DOI. This article is (C SAGE Publications and permission has been granted for this version to appear in e-Publications@Marquette. SAGE Publications does not grant permission for this article to be further copied/distributed or hosted elsewhere without the express permission from SAGE Publications. 
NOT THE PUBLISHED VERSION; this is the author's final, peer-reviewed manuscript. The published version may be

accessed by following the link in the citation at the bottom of the page.

NCATE. (2006b). NCATE standards revision. Retrieved August 25, 2007, fromwww.ncate.org/documents/Standards/May06_revision/GlossaryAd ditionsEdits.doc

NCATE. (2007). Professional standards for the accreditation of schools, colleges, and departments of education, 2008 edition. Retrieved July 11, 2007, from http://www.ncate.org/ institutions/revisedStds07.asp?ch $=4$

National Education Association. (1975). Code of ethics for the education profession. Retrieved May 23, 2006, from www.nea.org/aboutnea/code.html

Nespor, J. (1987). The role of beliefs in the practice of teaching. Journal of Curriculum Studies, 19(4), 317-328.

Noddings, N. (1984). Caring: A feminist approach to ethics and moral education. Berkeley: University of California Press.

Oser, F. K. (1994). Moral perspectives on teaching. Review of Research in Education, 20, 57-127.

Pajares, M. F. (1992). Teachers' beliefs and educational research: Cleaning up a messy construct. Review of Educational Research, 62(3), 307-332.

Pervin, L. A., \& John, O. P. (Eds.). (1999). Handbook of personality: Theory and research ( $2^{\text {nd }}$ ed.). New York: Guilford.

Peterson, K. M., Cross, L. E., Johnson, E. J., \& Howell, G. H. (2000). Diversity education for preservice teachers: Strategies and attitude outcomes. Action in Teacher Education, 22(2), 33-38.

Pettus, A. M., \& Allain, V. A. (1999). Using a questionnaire to assess prospective teachers' attitudes toward multicultural education issues. Education, 119(4), 651-658.

Pohan, C. A., \& Aguilar, T. E. (2001). Measuring educators' beliefs about diversity in personal and professional contexts. American Educational Research Journal, 38(1), 159-182.

Richardson, V. (1990). Significant and worthwhile change in teaching practice. Educational Researcher, 19(7), 10-18.

Richardson, V. (1996). The role of attitudes and beliefs in learning to teach. In J. Sikula (Ed.), Handbook of research on teacher education (pp. 102-119). New York: Simon \& Schuster.

Roberts, R. (2006, April). Assessing teacher dispositions. Presentation at the annual meeting of the American Association of Colleges for Teacher Education, San Diego.

Ryans, D. G. (1960). Characteristics of teachers. Washington, DC: American Council on Education.

Sachs. S. K. (2004). Evaluation of teacher attributes as predictors of success in urban schools. Journal of Teacher Education, 55(2), 177-187.

Schussler, D. L., Stooksberry, L. M., \& Bercaw, L. A. (2005, April). Conceptualizing dispositions: Intellectual, cultural, and moral domains

Journal of Teacher Education, Vol. 58, No. 5 (November/December 2007): pg. 397-411. DOI. This article is (C SAGE Publications and permission has been granted for this version to appear in e-Publications@Marquette. SAGE Publications does not grant permission for this article to be further copied/distributed or hosted elsewhere without the express permission from SAGE Publications. 
NOT THE PUBLISHED VERSION; this is the author's final, peer-reviewed manuscript. The published version may be accessed by following the link in the citation at the bottom of the page.

of teaching. Paper presented at the Annual Meeting of the American Educational Research Association, Montreal, Quebec, Canada.

Sleeter, C. E. (2001). Preparing teachers for culturally diverse schools: Research and the overwhelming presence of Whiteness. Journal of Teacher Education, 52(2), 94-106.

Sockett, H. (2006). Character, rules and relationships. In H. Sockett (Ed.), Teacher dispositions: Building a teacher education framework of moral standards (pp. 9-25). Washington, DC: AACTE Publications

Strickland, M., Weinstein, E., Thomas, J., Pierce, J., \& Stuckey, A. (2003, April). Of teacher dispositions, the ALCP and portfolios. Paper presented at Annual Meeting of the American Educational Research Association, Chicago.

Strike, K. A. (1996). The moral responsibilities of educators. In J. Sikula (Ed.), Handbook of research on teacher education (2nd ed., pp. 869892). New York: Macmillan.

Thompson, A. (1998). Not the color purple: Black feminist lessons for educational caring. Harvard Educational Review, 68(4), 522-554.

Washburne, C., \& Heil, L. M. (1960). What characteristics of teachers affect students' growth? The School Review, 68(4), 420-428.

Wilkerson, J. R. (2006, April 20). Measuring teacher dispositions: Standardsbased or morality-based? (ID No. 12493). Teachers College Record. Retrieved May 24, 2006, from www.tcrecord.org

Will, G. (2006, January 16). Ed schools vs. education. Newsweek. Retrieved August 24, 2007, from http://www .msnbc.msn.com/id/10753446/site/newsweek/

Wise, A. (2005, October 17). U.S. News and World Report: Editorial opinion. Retrieved January 25, 2006, from www .usnews.com/usnews/letters/articles/051114/141ett_5 .html

Wise, A. (2006, February 28). NCATE News: Wise to Hess, Will, and Leo. Retrieved May 25, 2006, from www.ncate .org/public/0228_postWise.asp?ch $=150$ 